Н.М. Храновська ${ }^{1}$, О.В. Скачкова ${ }^{1}$, О.І. Горбач ${ }^{1}$, В.М. Жукова ${ }^{1}$, О.Я. Главацький ${ }^{2}$, О.В. Земскова ${ }^{2}$, Г.В. Хмельницький ${ }^{2}$ І.М. Шуба ${ }^{2}$

\title{
Перший досвід використання імунотерапії на основі дендритних клітин в комплексному лікуванні хворих на гліобластому в Україні
}

\author{
${ }^{1}$ Національний інститут раку, Київ \\ ${ }^{2} Д У$ «нститут нейрохірурсії ім. акад. А.П. Ромоданова НАМН Украӥни», Київ \\ Одержано 10.06.2019 \\ Прийнято до друку 03.07.2019
}

DOI: $10.32471 /$ clinicaloncology.2663-466X.38.22510

\begin{abstract}
Актуальність. Низька ефективність традиційної терапії злоякісних гліом змушує наукову спільноту шукати альтернативні підходи до лікування цієї патології. Сьогодні активно розробляються варіанти імунотерапевтичного впливу на гліальні пухлини головного мозку. Метою роботи було дослідити можливість використання дендритних клітин (ДК), генерованих з моноцитів периферичної крові, для проведення імунотерапії (IT) у комплексному лікуванні хворих на гліобластому. Об'єкт і методи. Хворим на гліобластому IT на основі ДК призначали в ад'ювантному режимі, після основного лікування. ДК генерували з моноцитів периферичної крові та навантажували лізатом аутологічних пухлинних клітин. Аналіз фенотипічних характеристик генерованих ДК, а також популяційного і субпопуляційного складу лімфоцитів периферичної крові проводився методом проточної цитофлуориметрії. Результати. Ми встановили, що генеровані ДК до початку ІТ мають середній ступінь зрілості і цілком придатні для її проведення. Рівень експресії маркера CD83, який визначає ступінь зрілості дК, зростає на етапах проведення IT. Введення ДК-вакцини не супроводжувалося розвитком яких-небудь істотних побічних або токсичних реакцій у хворих. IT на основі ДК сприяє зменшенню відносної кількості супресорних клітин мієлоїдного походження (MDSC) у периферичній крові хворих. Висновки. ДК, генеровані з моноцитів периферичної крові хворих на гліобластому, мають середній ступінь зрілості, що свідчить про їх придатність для використання в ІТ. Найбільш суттєве підвищення ступеня зрілості ДК та найбільш виражені зміни у стані імунної системи у хворих на гліобластому зареєстровано після проведення 4-5 етапів IT на основі ДК. 3 урахуванням вивчення характеристик генерованих ДК та змін у стані імунної системи під час проведення IT розроблено методичні підходи до використання ДК у комплексному лікуванні хворих на гліобластому.
\end{abstract}

Ключові слова: гліобластома; імунотерапія; дендритні клітини; імуномоніторинг.

Гліобластома - найбільш розповсюджена та агресивна форма пухлин мозку, яка становить до $52 \%$ первинних новоутворень мозку і до 20\% всіх внутрішньочерепних пухлин. Стандартне лікування, що включає хірургічне видалення пухлини в максимально можливому об'єм із наступним хіміопроменевим лікуванням і ад'ювантною терапією темозоломідом, забезпечує дворічну виживаність лише у чверті хворих на гліобластому [1]. Додавання бевацизумабу до стандартного лікування сприяло збільшенню виживаності до 4 міс без прогресування, але ця терапія не виявила впливу на збільшення терміну загальної виживаності [2, 3]. Низька ефективність традиційної цитостатичної терапії змушує наукову спільноту шукати альтернативні підходи до лікування цієї патології.

Успіхи у вивченні природи злоякісних пухлин і клінічної значущості молекулярних і генетичних ознак пухлини зумовлюють пошук принципово нових методів лікування, в основі яких лежить вибіркове ураження клітин, генетично відмінних від нормальних клітин організму. Одним з таких методів $€$ імунотерапія (IT), яка грунтується на активації та посиленні процесів специфічної імунної відповіді організму на розвиток пухлини. Уже досягнуто певних успіхів в IT онкологічних захворювань. Так, наприклад, в США Управлінням з контролю якості харчових продуктів і лікарських препаратів (FDA) схвалено для широкого клінічного застосування близько 17 імунотерапевтичних препаратів [4]. Активно розробляються варіанти імунотерапевтичного впливу на гліальні пухлини Багато з цих варіантів успішно пройшли I і II фази клінічних випробувань. Однак, з урахуванням нечисленних досліджень, навіть при наявності обнадійливих результатів, доказова база методу залишається недостатньою [5].

Гліобластома вважається однією з найбільш «immune-cold» пухлин у порівнянні з іншими формами злоякісних ново- утворень. Зокрема, гліобластоми мають низький рівень інфільтрації Т-клітинами та характеризуються одним з найнижчих показників «мутаційного навантаження» (tumor mutation burden - TMВ). Вважається, що це призводить до меншої кількості пухлиноспецифічних неоантигенів і поганої імуногенності пухлини, що, в свою чергу, може обмежувати ефективність IT, в тому числі чекпойнт-інгібіторами [6].

Безсумнівний інтерес в плані протипухлинної IT викликають ад'юванти природного походження, такі як дендритні клітини (ДК) - головні антигенпрезентуючі клітини імунної системи. Основними функціями ДК є захоплення навколишніх та клітиноасоційованих антигенів, міграція крізь аферентні лімфатичні судини до Т-клітинних зон вторинних лімфоїдних органів, процесинг та презентація захоплених антигенів, ініціація потужної адаптивної імунної відповіді. Індукція диференціювання з попередників та навантаження ДК антигенами з пухлини in vitro дозволяють посилити імунну відповідь на низькоімуногенні антигени, зокрема пухлиноасоційовані антигени, відновити порушені in vivo етапи їх презентації імунокомпетентним клітинам [7, 8].

Оскільки ключова роль ДК в інтерналізації, процесингу та презентації антигенів встановлена лише декілька десятиріч тому, механізми дії вакцин даного типу вивчені недостатньо, а найбільш ефективні схеми проведення IT вакцинами на основі ДК у хворих на гліобластому перебувають на стадії розробки.

Тому метою роботи було дослідити можливість використання ДК, генерованих з моноцитів периферичної крові, для проведення IT у комплексному лікуванні хворих на гліобластому.

\section{ОБ'ЄКТ І МЕТОДИ ДОСЛІДЖЕННЯ}

Клінічні характеристики хворих. У дослідження були залучені 5 хворих: 3 чоловіки та 2 жінки. На момент проведення першої ДК-вакцинації вік хворих становив 27-70 років. У всіх 5 хворих 
діагноз гліобластоми, найбільш злоякісної гліоми IV ступеня анаплазії, був підтверджений патогістологічно.

У 3 хворих було проведено імуногістохімічне дослідження експресії гена $\mathrm{O}^{6}$-метилгуанін-ДНК-метилтрансферази (MGMT) та статусу його метилювання. У всіх випадках у пухлині було виявлено позитивну експресію та не відмічено метилювання гена $M G M T$, що було розцінено як ознаку низької чутливості до препарату темозоломіду.

Усім хворим було виконано резекцію пухлини у максимально можливому об'ємі: тотальне видалення пухлини 3 хворих; субтотальне - 1 ; парціальне - 1 . Локалізація первинної пухлини була такою: скронева ділянка ліворуч -1 хворий та праворуч -1 хворий; лобова ділянка праворуч -1 ; тім'яна ділянка праворуч -1 ; лобово-тім'яна ділянка 3 поширенням на мозолясте тіло - 1. Ад’ювантне лікування у всіх хворих включало променеву терапію на післяопераційну ділянку та хіміотерапію препаратом темозоломід, як в конкомітантному режимі (75 мг/м² поверхні тіла) на фоні опромінення, так і повторними курсами хіміотерапії темозоломідом за Stuppпротоколом [9].

Усі хворі були сповіщені про проведення досліджень і дали інформовану згоду на їх виконання. Дослідження проводили згідно з етичними нормами, прийнятих українським законодавством (Протокол засідання комісії з питань етики № 2 ДУ «Інститут нейрохірургії ім. акад. А.П. Ромоданова НАМН України» від 15.04.2019 р.).

ДК генерували з моноцитів периферичної крові з додаванням ростових факторів та факторів дозрівання (гранулоцитарно-макрофагальний колонієстимулюючий фактор, інтерлейкін-4, ліпополісахарид, інтерферон- $\alpha$ ), в якості джерела пухлинних антигенів використовували лізат пухлинних клітин (всі маніпуляції проводили з дотриманням правил асептики). На 8-му добу культивування ДК робили підрахунок і оцінку життєздатності ДК в камері Горяєва в $0,4 \%$ розчині трипанового синього. Отримували ДК з життєздатністю не менше 95\%, домішка лімфоцитів становила не більше $20 \%$.

IT на основі ДК призначали в ад’ювантному режимі, після хіміопроменевого лікування. У 2 з 5 хворих IT застосовували в комплексному лікуванні рецидиву гліобластоми через 6 та 10 міс після встановлення діагнозу.

Кількість ДК на одне введення становила 2,0-5,0 • $10^{6}$. ДК вводили внутрішньошкірно паравертебрально. Усім хворим проводили 5 ін'єкцій з періодичністю 1 раз на місяць.

На 3 етапах IT - до терапії, на початку терапії (1-2 введення ДК-вакцини) та в кінці терапії (4-5 введення ДК вакцини) - хворим проводили гематологічні та імунологічні дослідження. Також в дослідженні були використані показники 15 практично здорових людей.

Імунологічні методи дослідження. Аналіз фенотипічних характеристик ДК проводили методом проточної цитофлуориметрії з використанням моноклональних антитіл до антигенів CD83, CD86, CD 11c, HLA-DR та HLA-ABC.

Дослідження популяційного і субпопуляційного складу лімфоцитів периферичної крові включав визначення експресії маркерів: $\mathrm{CD}^{+}, \mathrm{CD}^{2} 9^{+}, \mathrm{CD}^{+}, \mathrm{CD} 8^{+}, \mathrm{CD} 16^{+} 56^{+}$(для дослідження T-, В-лімфоцитів, NK-клітин); HLA-DR ${ }^{+}, \mathrm{CD}_{3} 8^{+}$(активованих лімфоцитів); HLA-DR $-11 \mathrm{~b}^{+} 33^{+}$(для супресорних клітин мієлоїдного походження - myeloid-derived suppressor cells - MDSC).

Аналіз проводили за допомогою методу прямої імунофлуоресценції з використанням моноклональних антитіл, кон'югованих з флуоресцентними барвниками FITC, РЕ, АРС, PE-Cy5 («Becton Dickinson», США; «Caltag», США). Усі цитометричні дослідження виконували на проточному цитофлуориметрі FACSCalibur («Becton Dickinson», США), що оснащений двома лазерами (довжина хвилі 488 та 625 нм), з використанням програми CellQuest-PRO (США) для отримання та аналізу даних.

Гематологічні дослідження. Визначали загальне та абсолютне значення лейкоцитів, моноцитів та лімфоцитів периферичної крові, рівень гемоглобіну, тромбоцитів та гематокрит.

Статистичну обробку проводили із застосуванням пакета програм Statistica 10.0 (Stasoft Inc., США). Для порівняння даних у двох групах використовували t-критерій Стьюдента і тест Манна - Уїтні. Різниця вважалася статистично достовірною при $\mathrm{p}<0,05$.

\section{РЕЗУЛЬТАТИ ДОСЛІДЖЕННЯ}

Серед 5 досліджуваних пацієнтів одна хвора з рецидивною гліобластомою померла від прогресії пухлинного процесу через 12 міс після першої операції з видалення новоутворення та через 3 міс після початку IT. Інші 4 хворих живі та перебувають під спостереженням, що включає регулярні клінічні огляди, стандартні лабораторні аналізи (загальний та біохімічний аналіз крові, електрокардіографія та ін.) і нейровізуалізаційний МРТ-моніторинг. В одному випадку у хворого з рецидивною гліобластомою за даними останнього МРТ-контролю встановлено прогресію захворювання у вигляді мультицентричного розповсюдження пухлини у головному мозку. МРТ-моніторинг решти 3 хворих не виявив ознак пухлинної прогресії.

У табл. 1 представлено характеристики досліджуваної групи та результати спостереження.

Нами встановлено, що кількість генерованих ДК із моноцитів периферичної крові досліджуваних хворих дещо зменшена на початкових етапах IT щодо значень у практично здорових людей та становить $3,05 \pm 0,47 \cdot 10^{6}$ та $3,87 \pm 0,32 \cdot 10^{6}$ відповідно. На наступних етапах IT кількість генерованих ДК дещо збільшувалася, однак ці зміни відбувалися на рівні тенденції. Слід зазначити, що у всіх досліджуваних хворих нам вдалося отримати достатню кількість життєздатних ДК для проведення IT.

Ступінь зрілості вважається вкрай важливою характеристикою ДК при їх використанні в якості природних ад'ювантів в складі протипухлинних вакцин. Тож ми провели оцінку фенотипічних характеристик ДК на кінцевому етапі виготовлення вакцини. Відомо, що дозрівання ДК асоційоване з експресією молекули CD83, а також посиленням експресії молекул HLA-DR та CD86. Нами встановлено, що ДК, генеровані з моноцитів периферичної крові хворих на гліобластому до початку терапії, мають середній ступінь зрілості, а саме, рівень експресії костимуляторних молекул CD86 ${ }^{+} \mathrm{HLA}^{-\mathrm{DR}^{+}}$ становить $70,28 \pm 3,93 \%$ та CD $83^{+}-22,00 \pm 7,94 \%$ (рис. 1 ), і вони цілком придатні для проведення IT [10-12].

Результати наших досліджень показали, що з кожним наступним етапом IT ступінь зрілості генерованих ДК значно зрос-

Таблиця 1. Характеристики досліджуваної групи та результати спостереження

\begin{tabular}{|c|c|c|c|c|c|c|c|}
\hline Хворі & $\begin{array}{c}\text { Вік на мо- } \\
\text { мент першої } \\
\text { дендритно- } \\
\text { клітинної вакци- } \\
\text { нації, років } \\
\end{array}$ & Стать & Локалізація пухлини & $\begin{array}{c}\text { Загальний пе- } \\
\text { ріод спостере- } \\
\text { ження, міс }\end{array}$ & $\begin{array}{l}\text { Час до на- } \\
\text { стання ре- } \\
\text { цидиву, міс }\end{array}$ & $\begin{array}{c}\text { Термін від першої опера- } \\
\text { ції з видалення пухлини } \\
\text { до першої ДК-вакцинації, } \\
\text { міс }\end{array}$ & $\begin{array}{c}\text { Результат спо- } \\
\text { стереження: } \\
\text { живий - 1, } \\
\text { помер - } 0\end{array}$ \\
\hline Хворий № 1 & 48 & жін. & $\begin{array}{c}\text { Лобово-тім'яна ділянка } \\
3 \text { поширенням на мозо- } \\
\text { лясте тіло }\end{array}$ & 11 & Не виявлено & 5 & 1 \\
\hline Хворий № 2 & 27 & чол. & Лобова ділянка праворуч & 12 & Не виявлено & 3 & 1 \\
\hline Хворий № 3 & 48 & чол. & Тім'яна ділянка праворуч & 18 & 10 виявлено & 11 & 1 \\
\hline Хворий № 4 & 70 & чол. & $\begin{array}{c}\text { Скронева ділянка пра- } \\
\text { воруч }\end{array}$ & 11 & Не виявлено & 5 & 1 \\
\hline Хворий № 5 & 36 & жін. & Скронева ділянка ліворуч & 12 & 6 виявлено & & 0 \\
\hline
\end{tabular}



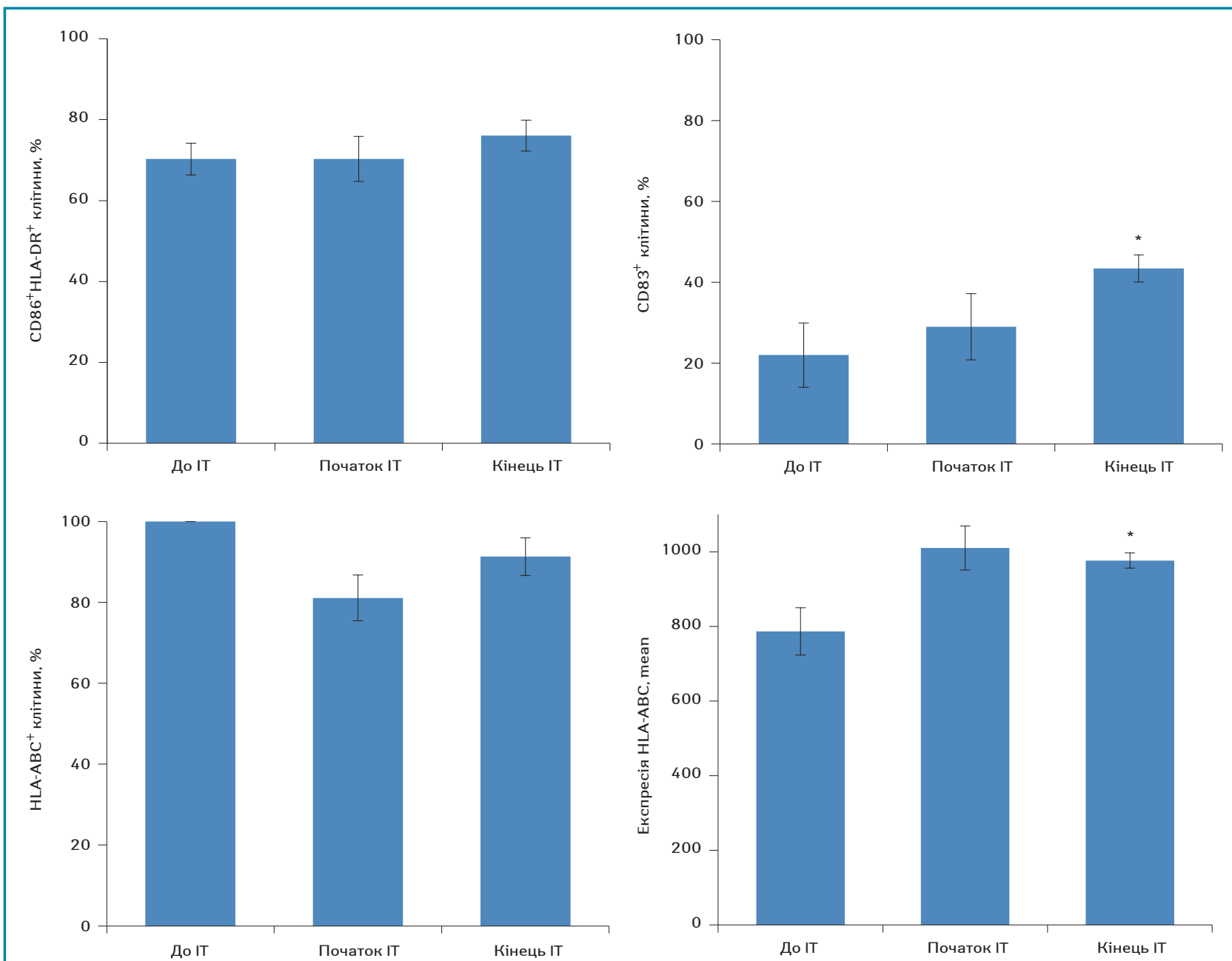

Рис. 1. Показники імунофенотипування генерованих ДК, використаних для проведення IT хворим на гліобластому. * $\mathrm{p} \leqslant 0,05$ у порівнянні із показниками до IT

тає. Так, на 4-5-му етапах IT генеровані ДК мали максимально високий ступінь зрілості завдяки зростанню рівня експресії молекули $\mathrm{CD}^{2} 3^{+}$в 1,98 раза проти початкових етапів $(\mathrm{p}=0,039)$.

Відомо, шо, на відміну від інших антигенпрезентуючих клітин, ДК мають декілька додаткових механізмів, які дозволяють їм представляти екзогенні антигени в комплексі з молекулами головного комплексу гістосумісності (major histocompatibility complex - MHC) не тільки II класу, але й I класу, що є ключовим моментом для генерації цитотоксичних Т-лімфоцитів, здатних до інактивації пухлинних клітин. Це так звана перехресна презентація антигенів, коли антигени, що зазвичай презентуються молекулами МНС II класу, можуть бути представлені також і молекулами I класу [13].

Наші дослідження показали, що відносна кількість молекул HLA-ABC (молекули MHC I типу) та HLA-DR (молекули MHC II типу) на генерованих ДК значно не змінювалися під час проведення IT. Спостерігалось незначне збільшення відносної кількості молекул HLA-DR на рівні тенденції. Однак виявлено статистично достовірну різницю у рівні експресії молекул HLAABC, що визначалася за допомогою вимірювання середньої інтенсивності експресії (mean). Саме цей показник свідчить про збільшення щільності молекул HLA-ABC на мембрані ДК, що може опосередковано свідчити про активізацію перехресної презентації пухлинних антигенів. Так, на кінцевому етапі IT се-

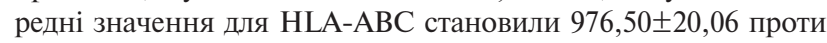
$783,38 \pm 63,43$ до ії проведення $(\mathrm{p}=0,022)$.

Результати досліджень показали, що введення ДК-вакцини не супроводжувалася розвитком будь-яких істотних побічних або токсичних реакцій у хворих. Не відмічено значного погіршення самопочуття пацієнтів і розвитку побічних явищ у вигляді алергічних або аутоімунних розладів, регіонарної лімфаденопатії, пов'язаних із введенням вакцини.

Ми встановили, що проведення IT на основі ДК суттєво не впливає на гематологічні показники периферичної крові хворих. Слід зазначити, що до початку IT загальна кількість гранулоцитів та моноцитів була статистично достовірно більшою за показники у практично здорових людей $(p=0,02)$, а проведення терапії сприяло їх нормалізації. Статистично достовірні зміни відмічалися лише для кількості лімфоцитів периферичної крові. Встановлено, що їх кількість після проведення IT збільшилася у 1,9 раза порівняно з показниками до терапії ( $\mathrm{p}=0,049$; рис. 2$)$.

Також нами встановлено, що проведення IT на основі ДК не вплинуло на рівень гемоглобіну, тромбоцитів та гематокрит у хворих на гліобластому, вони залишалися на рівні значень практично здорових людей.

Одним із завдань нашого дослідження було проведення імуномоніторингу у хворих на гліобластому під час застосування IT. Ми встановили, що IT на основі ДК-вакцини значно не впливає на кількість основних популяцій лімфоцитів периферичної крові (Т-, В-лімфоцитів та NK) в динаміці проведення IT (табл. 2).

Слід зазначити, що кількість $\mathrm{CD}^{+} \mathrm{T}$-лімфоцитів та $\mathrm{CD} 4^{+}$ T-клітин-хелперів до початку проведення IT була достовірно меншою за цей показник у практично здорових людей $(\mathrm{p} \leqslant 0,05)$. Проведення ДК-вакцинотерапії сприяло нормалізації цих 

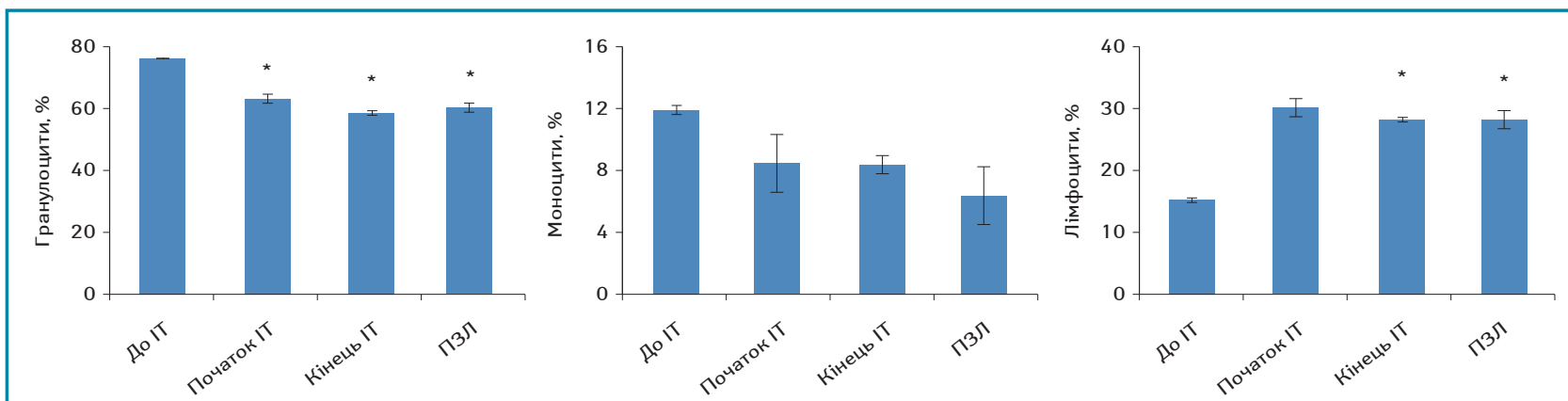

Рис. 2. Зміни гематологічних показників периферичної крові хворих на гліобластому під час проведення IT на основі ДК. ПЗЛ - практично здорові люди. * $\mathrm{p}<0,05$ у порівнянні із показниками до IT

Таблиця 2. Зміни у основних популяціях лімфоцитів периферичної крові у хворих на гліобластому на етапах проведення IT на основі ДК

\begin{tabular}{|c|c|c|c|c|c|c|}
\hline Етапи IT & $\mathrm{CD3}^{+}, \%$ & $\mathrm{CD}^{2}{ }^{+}, \%$ & $\mathrm{CD4}^{+}, \%$ & $\mathrm{CD}^{+}, \%$ & $\mathrm{CD3}^{-16} \mathbf{6}^{+} 56^{+}, \%$ & $\mathrm{CD3}^{+} 16^{+} 56^{+}, \%$ \\
\hline До ІТ & $57,20 \pm 2,29$ & $10,80 \pm 3,46$ & $25,60 \pm 3,41$ & $26,60 \pm 3,19$ & $21,80 \pm 3,48$ & $6,20 \pm 0,86^{\star}$ \\
\hline Початок IT & $55,44 \pm 1,71$ & $8,56 \pm 0,82$ & $30,56 \pm 1,21$ & $28,89 \pm 1,23$ & $26,00 \pm 1,86$ & $6,44 \pm 0,48^{*}$ \\
\hline Кінець IT & $61,64 \pm 0,77$ & $7,18 \pm 0,33$ & $30,18 \pm 0,91$ & $34,45 \pm 0,58$ & $22,09 \pm 0,70$ & $8,00 \pm 0,46^{*}$ \\
\hline Практично здорові люди & $75,30 \pm 3,80$ & $8,00 \pm 1,70$ & $45,70 \pm 2,70$ & $21,30 \pm 2,10$ & $16,00 \pm 0,45$ & $3,73 \pm 0,37$ \\
\hline
\end{tabular}

${ }^{\star} \mathrm{p}<0,05$ у порівнянні із показниками практично здорових людей.

показників. Також під час проведення IT спостерігалося значне збільшення кількості цитотоксичних $\mathrm{CD} 8^{+}$Т-лімфоцитів

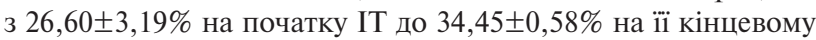
етапі, однак ці зміни відбувалися на рівні тенденції.

Також ми встановили, що кількість MDSC з фенотипом HLA-DR ${ }^{-} 11 \mathrm{~b}^{+} 33^{+}$під час проведення IT зменшується у 2,39 раза ( $\mathrm{p}=0,023$; рис. 3$)$.

Нами було встановлено, що до проведення IT кількість MDSC у периферичній крові хворих на гліобластому перевищувала показники у практично здорових людей у 4,34 раза та становила $55,20 \pm 9,66 \%$ проти $11,9 \pm 2,13 \%$ відповідно $(p=0,004)$.

\section{ОБГОВОРЕННЯ}

Узагальнена схема створення протипухлинних вакцин на основі ДК полягає в наступному: вирошування аутологічних ДК у достатніх кількостях поза організмом (in vitro) з попередників, навантаження пухлинними антигенами, індукція їхнього дозрівання і введення хворому. Протипухлинний ефект досягається повторними введеннями ДК в режимі вакцинотерапії. Однак перед дослідниками залишається ще багато відкритих питань. Зокрема, не визначені оптимальні способи, режими та схеми введення ДК, не розроблені протоколи поєднання IT на базі ДК з основним лікуванням хворих зі злоякісними новоутвореннями, не з'ясовано схему проведення імуномоніторингу терапії [14]. Саме цим проблемам було присвячене наше дослідження.

Слід зазначити, що чітких критеріїв стандартизації ДК при створенні протипухлинних вакцин не існує. Відомо, що ДК повинні відповідати цілій низці вимог, які відобража-

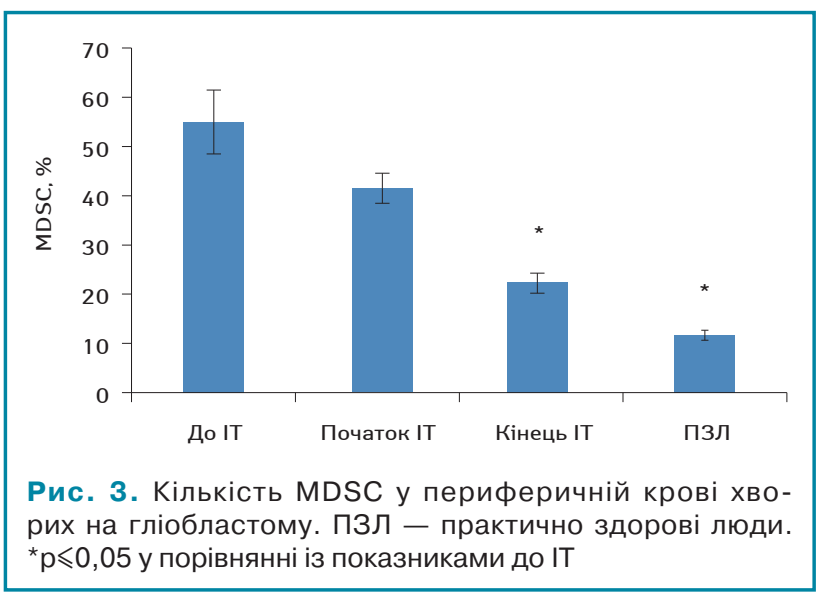

ють їх здатність презентації антигенів і стимуляції Т-клітин, бути життездатними, експресувати високий рівень маркерів зрілості, костимуляторних молекул і молекул адгезії, секретувати цитокіни, активувати цитотоксичні Т-лімфоцити і Th1опосередковану імунну відповідь [15].

Як ми показали у попередніх дослідженнях, у онкологічних хворих функціональна активність ДК, отриманих з попередників, як правило, знижена. Зокрема, вони часто є нечутливими до багатьох активуючих стимулів і залишаються незрілими. Протипухлинна хіміо- та променева терапія також може знижувати ефективність і гальмувати дозрівання ДК, що, в свою чергу, може лімітувати і ускладнювати застосування ДК [16]. Результати нашого дослідження показали, що ДК, генеровані з моноцитів периферичної крові хворих на гліобластому, також мають дещо знижені кількісні та функціональні показники зрілості щодо показників практично здорових людей.

Незважаючи на численні відомості про зміни у стані імунної системи під впливом IT, досі остаточно не визначені iї найбільш важливі імунологічні критерії. Одним з можливих пояснень цього є багатофункціональність імунної системи та плейотропність іiї ефектів, що ускладнює можливість прогнозу на підставі окремо взятих показників [17].

Наразі багато дослідників вказують на ключову роль MDSC у розвитку пухлин. Доведено, що ця популяція клітин володіє безперечним ефектом імунної супресії, що призводить до погіршення імунного нагляду і порушення протипухлинної цитотоксичності $[18,19]$. У здорових осіб MDSC виявлені переважно у кістковому мозку і в невеликій кількості в циркуляції. При нормальних фізіологічних умовах незрілі MDSC залишають кістковий мозок і мігрують у периферичні лімфоїдні органи, де диференціюються в макрофаги, ДК або гранулоцити [20]. При патологічних умовах - пухлинному рості, інфекціях, аутоімунних захворюваннях, запаленні MDSC репрограмуються і набувають імуносупресорних властивостей. Клінічні спостереження показали, що кількість MDSC у пацієнтів онкологічного профілю пов'язана зі стадією захворювання, розмірами пухлини, наявністю метастазів та виживаністю [21-23].

Результати наших досліджень збігаються з даними інших авторів, які вказують на значне збільшення кількості циркулюючих MDSC у хворих на гліобластому. Статистично достовірне зменшення їх кількості під час проведення IT на основі ДК може в подальшому слугувати імунологічним критерієм ефективності проведеної терапії. Однак ці дослідження потребують залучення більшої когорти хворих у дослідження. 
Загалом результати імунологічних досліджень свідчать про те, що найбільш виражені зміни у стані імунної системи у хворих на гліобластому зареєстровано після проведення 4-5 етапів IТ на основі ДК.

Отже, у нашому пілотному дослідженні були розроблені методичні підходи для використання ДК, генерованих in vitro 3 моноцитів периферичної крові, в якості природних ад’ювантів у складі протипухлинних вакцин в комплексному лікуванні хворих на гліобластому.

\section{ВИСНОВКИ}

1. Встановлено, що ДК, генеровані з моноцитів периферичної крові хворих на гліобластому, мають середній ступінь зрілості, що свідчить про їх придатність для використання в IT.

2. Рівень експресії маркера CD83, який визначає ступінь зрілості генерованих ДК, зростає на етапах проведення IT хворих на гліобластому $(\mathrm{p}=0,039)$.

3. Введення ДК-вакцини не супроводжується розвитком будь-яких істотних побічних або токсичних реакцій у хворих на гліобластому.

4. Проведення IT на основі ДК практично не вплинуло на гематологічні показники у хворих на гліобластому, за винятком відносної кількості лімфоцитів. Після проведення IT їх кількість зростала у 1,9 раза у порівнянні із вихідними показниками $(\mathrm{p}=0,049)$.

5. IT на основі ДК сприяє зменшенню відносної кількості MDSC у периферичній крові хворих на гліобластому $(\mathrm{p}=0,006)$.

6. На основі вивчення характеристик генерованих ДК та змін у стані імунної системи під час проведення IT розроблено методичні підходи до використання ДК у комплексному лікуванні хворих на гліобластому.

\section{СПИСОК ВИКОРИСТАНОÏ ЛІТЕРАТУРИ}

1. Erhart, F., Buchroithner, J., Reitermaier, R., Fischhuber, K., Klingenbrunner, S. Sloma, I., ... Visus, C. (2018). A characterization of dendritic cells and their role in immunotherapy in glioblastoma: from preclinical studies to clinical trials. Acta Neuropathologica Communications, 6, 135. https://doi.org/10.1186/s40478-018-0621-2.

2. Borisov, K. E., \& Sakaeva, D. D. (2015). Immunotherapy of malignant gliomas: current status and future directions. Malignant Tumours, 2. doi: 10.18027/2224-5057-2015-2

3. Srivastava, S., Jackson, C., Kim, T., Choi, J., \& Lim, M. (2019). A characterization of dendritic cells and their role in immunotherapy in glioblastoma: from preclinical studies to clinical trials. Cancers, 11(4), pii: E537. doi: 10.3390/cancers11040537.

4. Kong, Z., Wang, Y., \& Ma, W. (2018). Vaccination in the immunotherapy of glioblastoma. Human Vaccines \& Immunotherapeutics, 14(2), 255-268 https://doi.org/10.1080/21645515.2017.1388481

5. Schaller, H. T., \& Sampson, H. J. (2017). Advances and challenges: dendritic cell vaccination strategies for glioblastoma. Expert Review of Vaccines, 16(1), 27-36. doi: 10.1080/14760584.2016.1218762.

6. Goodman, A. M., Kato, S., Bazhenova, L., Patel, S. P., Frampton, G. M., Miller, V., ... Kurzrock, R. (2017). Tumor mutational burdenasanin dependent predictor of response to immunotherapy in diverse cancers. Molecular Cancer Therapeutics, 16(11), 2598-2608. doi: $10.1158 / 1535-7163$

7. Fehres, C. M., J. Unger, W. W., Garcia-Vallejo, J. J., \& Kooyk van, Y. (2014). Understanding the biology of antigen cross-presentation for the design of vaccines against cancer. Frontiers in Immunology, 5, 149-159. doi: 10.3389/fimmu.2014.00149.

8. Smart, A. C., Margolis, C. A., Pimentel, H., He, M. X., Miao, D., Adeegbe, D., Van Allen, E. M. (2018). Intron retention is a source of neoepitopes in cancer. Nature Biotechnology, 36, 1056-1058. doi: 10.1038/nbt.4239.

9. Stupp, R., Mason, W. P., Van den Bent, M. J., Weller, M., Fisher, B., \& Taphoorn, M. J. (2005). Radiotherapy plus concomitant and adjuvant temozolomide for glioblastoma. The New England Journal of Medicine, 352, 987-996. doi: mide for glioblastoma. The

10. Lesterhuis, W. J., de Vries, I. J., Adema, G. J., \& Punt, C. J. (2004). Dendritic cell-based vaccines in cancer immunotherapy: an update on clinical and immunological results. Annals of Oncology, 15(4), iv145-iv151. doi: 10.1093/annonc/mdh919.

11. Roche, P. A., \& Furuta, K. (2015). The ins and outs of MHC class II-mediated antigen processing and presentation. Nature Reviews Immunology, 5(4): 203-216. doi: $10.1038 /$ nri3818

12. Khranovska, N. M., Skachkova, O. V., Sovenko, V. M., Sydor, P. I., Inomistova, M. V., \& Melnyk, V. O. (2016). Phenotypic and functional properties of generated dendritic cells in lung cancer patients. Cell and Organ Transplantology, 4(2), 162-166. doi: 10.22494/cot.v4i2.63

13. Joffre, O. P., Segura, E., Savina, A., \& Amigorena, S. (2012). Cross-presentation by dendritic cells. Nature Reviews Immunology, 12, 557-569. doi: 10.1038/nri3254.

14. Geginat, J., Nizzoli, G., \& Paroni, M. (2015). Immunity to pathogens taught by specialized human dendritic cell subsets. Frontiers in Immunology, 6, 527. doi 10.3389/fimmu.2015.00527.

15. Richter, C., Thieme, S., \& Bandoła, J. (2013). Generation of inducibleim mortalized dendritic cells with proper immune function in vitro and in vivo. PLoS One, 8(4), 62621

16. Храновская, Н. Н., Крячок, И. А., Ганул, В. Л. Воробьева, Л. И., Гриневич, Ю. А., Орел, В. Э., ... Горбач, А. И. (2014). Разработка, обоснование и оценка эффективности противоопухолевой вакцинотерапии на основе дендритных клеток у больных со злокачественными новообразованиями. Клінічна онкологія, (2), 62-70.

17. Herman, W., Pagès, F., Sautès-Fridman, C., \& Galon, J. (2012). The immune contexture in human tumours: impact on clinical outcome. Nature, $12,9 \mathrm{p}$
18. Bronte, V., Brandau, S., Chen, S.-H., Colombo, M. P., Frey, A. B., Greten, T. F., ... Gabrilovich, D. I. (2015). Recommendations for myeloid-derived suppressor cell nomenclature and characterization standards. Nature Communications, 7, 12150. doi: $10.1038 /$ ncomms 12150 .

19. Громакова, И. А., Сорочан, П. П., Прохач, Н. Э., Пономарев, И. Н., \& Громакова, И. С. (2016). Супрессорные клетки миелоидного происхождения - новая терапевтическая цель в онкологии. Український радіологічний журнал, XXIV, 3, 66-75. 20. Montero, A. J., Finke, J., \& Montero, A. J. (2014). Myeloid-derived suppressor cells in cancer: therapeutic, predictive, and prognostic implications. Seminars in Oncology, 41 (2), 174-184. doi: 10.1053/j.seminoncol.2014.02.003.

21. Zhang, B., Wang, Z., Wu, L., Zhang, M., Li, W., Ding, J. ... Zhao, K. (2013). Circulating and tumor-infiltrating myeloid-derived suppressor cells in patients with colorectal carcinoma. PLoS One, 8(2), e57114. doi: 10.1371/journal.pone.0057114.

22. Wang, L. (2013). Increased myeloid-derived suppressor cells in gastric cancer correlate with cancer stage and plasma S100A8/A9 proinflammatory proteins. The Journal of Immunology, 190(2), 794-804. doi: 10.4049/jimmunol. 1202088.

23. Meyer, C., Cagnon, L., Costa-Nunes, C.M., Baumgaertner, P., Montandon, N., Leyvraz, L., ... Speiser, D. E. (2014). Frequencies of circulating MDSC correlate with clinical outcome of melanoma patients treated with ipilimumab. Cancer Immunology, Immunotherapy, 63(3), 247-257. doi: 10.1007/s00262-013-1508-5.

Первый опыт использования иммунотерапии на основе дендритных клеток в комплексном лечении больных глиобластомой в Украине

Н.Н. Храновская ${ }^{1}$, О.В. Скачкова ${ }^{1}$, А.И. Горбач ${ }^{1}$, В.М. Жукова А.Я. Главацкий ${ }^{2}$ О.В. Земскова ${ }^{2}$ Г.В. Хмельницкий, И.М. Шуба ${ }^{2}$

'Национальный институт рака, Киев

${ }^{2}$ ГУ «Институт нейрохирургии им. акад. А.П. Ромоданова НАМН Украины", Киев

Резюме. Актуальность. Низкая эффективность традиционной терапии глиобластомы заставляет научное сообщество искать альтернативные подходы клечению данной патологии. Сегодня активно разрабатываются варианты иммунотерапевтического влияния на глиальные опухоли головного мозга. Целью работы было исследовать возможность использования дендритных клеток (ДК), генерируемых из моноцитов периферической крови, для проведения иммунотерапии (ИТ) в комплексном лечении больных глиобластомой. Объект и методы. Больным глиобластомой ИТ на основе ДК проводили в адъювантном режиме, после основного лечения. Анализ фенотипических характеристик ДК, а также популяционного и субпопуляционного состава лимфоцитов периферической крови проводился методом проточной цитофлуориметрии. Результаты. Установлено, что ДКдо начала терапии имеют среднюю степень зрелости и вполне пригодны для проведения ИТ. Уровень экспрессии маркера CD83, который определяет степень зрелости генерируемых ДК, повышается на этапах проведения ИТ. Введение ДК-вакцины не сопровождалось развитием каких-либо существенных побочных или токсических реакций у больных. ИТ на основе ДК способствует уменьшению относительного количества супрессорных клеток миелоидного происхождения (MDSC) в периферической крови больных. Выводы. ДК, генерируемые из моноцитов периферической крови больных глиобластомой, имеют среднюю степень зрелости, что свидетельствует об их пригодности для использования в ИТ. Наиболее существенное повышение степени зрелости ДК и наиболее выраженные изменения в состоянии иммунной системы у больных глиобластомой зарегистрировано после проведения 4-5 этапов ИТ на основе ДК. С учетом изучения характеристик генерируемых ДК и изменений в состоянии иммунной системы при проведении ИТ разработаны методические подходы к использованию ДК в комплексном лечении больных глиобластомой.

Ключевые слова: глиобластома; иммунотерапия; дендритные клетки; иммуномониторинг.

The first experience of using dendritic cells immunotherapy in complex treatment of patients with glioblastoma in Ukraine

N.M. Khranovska ${ }^{l}$, O.V. Skachkova ${ }^{l}$, O.I. Gorbach ${ }^{\prime}$, V.M. Zhukova', O.Ya. Glavatskyi ${ }^{2}$, O.V. Zemskova ${ }^{2}$, G.V. Khmelnitskyi ${ }^{2}$, I.M. Shuba ${ }^{2}$

${ }^{1}$ National Cancer Institute, Kyiv

${ }^{2} S I$ «Romodanov Neurosurgery Institute of the NAMS of Ukraine», Kyiv

Summary. Background. The low effectiveness of traditional therapy in gliomas causes the scientific community to develop 


\section{Оригінальні статті / Original Articles}

the new treatment approaches. Nowadays, some variants of immunotherapy (IT) for glial tumor cells are actively investigate. The aim was to investigate the possibility of autologous dendritic cells (DCs) application for immunotherapy in combination treatment for patients with glioblastoma. Matherials and methods. IT based on DC was administered as adjuvant treatment for patients with glioblastoma after the basic treatment. DC was generated from peripheral blood monocytes and loaded with lysate of autologous tumor cells. The phenotypic analysis of the autologous generated DC and populations of peripheral blood lymphocytes was performed by flow cytometry. Results. We have found that the generated DC before the IT had an average degree maturity and suitable for implementation as vaccine. The expression level of the CD83 surface receptor, which determines the degree of DC maturity, increased at the all stages of IT. The administration of DC vaccine was not accompanied by any significant adverse or toxic reactions in patients. DC based IT promoted the decreasing of myeloid-derived suppressor cells (MDSCs) relative number in peripheral blood of patients. Conclusions. DCs, generated from autologous peripheral blood monocytes from pa- tients with glioblastoma, had an average level of maturity but were suitable for IT application. The most significant increasing in the DC maturity degree and pronounced changes in the immune system state in patients with glioblastoma was recorded after 4-5 stages of IT based on DC. Based on the study of the DC characteristics and state changes of the immune system during the IT, methodological approaches for the DC application as a complex treatment for patients with glioblastoma was developed.

Key words: glioblastoma; immunotherapy; dendritic cells; immune monitoring.

\section{Адреса:}

Скачкова Оксана Володимирівна

03022, Київ, вул. Ломоносова, 33/43

Національний інститут раку

E-mail: oksanaskachkova@ukr.net 